DOI: 10.19195/0137-1150.163.65

\author{
MARTA CHASZCZEWICZ-RYDEL \\ Uniwersytet Wrocławski, Polska \\ marta.chaszczewicz@uwr.edu.pl
}

\title{
O młodych i starych we współczesnej literaturze serbskiej (Matija Bećković, Biljana Srbljanović)
}

\begin{abstract}
uzupetnieniem kultu urody i młodości jest bajka o starzeniu się szczęśliwym, bezbolesnym, niepozbawiajacym nas życiowych przyjemności. [...] Takie starzenie się jest dziś wręcz obowiazkiem. Nikogo nie obciąża, nie zmusza do współczucia. Nie irytuje.
\end{abstract}

Kinga Dunin ${ }^{1}$

Biologiczny proces starzenia się w ujęciu kulturoznawczym przedstawia się jako kształtowany przez idee i regulowany społecznymi konwencjami, dlatego wiek uznawany jest tu za jedną z ważniejszych zmiennych, która decyduje o społecznej roli, statusie i o relacjach danej jednostki ${ }^{2}$. Studia krytyczne nad tą kategorią zwracają uwagę, że bywa ona jednym z narzędzi reprodukowania nierówności. $Z$ kolei socjologiczna refleksja na temat starości porusza przede wszystkim kwestie zmian społecznych zachodzących w Europie, opisuje zjawiska emancypacji ludzi młodych ${ }^{3}$ i afirmacji młodości. Procesy te pociągają za sobą konsekwencje na poziomie relacji międzyludzkich, a więc są źródłem nowych antagonizmów między pokoleniami, nowych oczekiwań i prób adaptacji poszczególnych generacji do warunków życia w społeczeństwie konsumpcyjnym, a także istotnych przewartościowań tradycyjnego stosunku do starzenia się.

${ }^{1}$ K. Dunin, Czego chcecie ode mnie, Wysokie Obcasy?, Warszawa 2002, s. 55-56.

2 Por. Wstęp do kulturoznawstwa, przeł. M. Kaczyński, J. Łoziński, T. Rosiński, Poznań 2007, s. 152.

3 J. Baudrillard, Społeczeństwo konsumpcyjne. Jego mity i struktury, przeł. S. Królak, Warszawa 2006, s. 184. 
Przedstawione powyżej spektrum problemów przenika do różnorakich gatunków współczesnej literatury, gdzie splata się z rozmaitymi dyskursami, przyjmując diametralnie odmienne formy, co chciałabym ukazać na przykładzie analizy porównawczej tekstów dwojga bardzo ważnych przedstawicieli serbskiej kultury, generacyjnie niespowinowaconych i o skrajnie odmiennych poglądach politycznych, tj. dramatopisarki Biljany Srbljanović oraz poety Matiji Bećkovicia.

Matija Bećković jest twórcą w Serbii doskonale rozpoznawalnym, uważanym za poetę narodowego, o czym świadczy imponująca bibliografia ${ }^{4}$, a także ilość otrzymanych nagród i oficjalnych wystąpień; nade wszystko jednak powodem tego przyporządkowania są takie cechy jego utworów, jak ideologiczne przesycenie tematyką bogoojczyźnianą, opieranie się na mitach narodowych, dociekaniach mentalnościowych, historiozoficznych. Mogłoby sie wydawać, że na tym tle dość wyraźnie wyróżnia się wydany w 2007 roku zbiór Kad budem mlađi, z którym do poezji Bećkovicia przedostaje się retoryka bulwarowa oraz związane z propagandą młodości tezy zaczerpnięte ze współczesnej prasy poradnikowej czy kanałów lifestylowych. Zasadnicza tematyka tego tomu jest zdominowana przez komiczne przeciwstawienie dwóch genereacji, lecz towarzyszy jej immanentna obecność struktur retorycznych poważnego dyskursu politycznego oraz silne akcenty ideologiczne.

Podmiot mówiący skrywa się pod maską eksperymentującego, infantylnego starca zatraconego w kulcie młodości. Obsesyjnie powtarza on tytułową formułę: „Gdybym był młodszy...”, a następnie przytacza praktyki prozdrowotne i kuracje odmładzające, którym chciałby się poddać, gdyby mógł odwrócić rytm zegara biologicznego. Komizm sytuacyjny wywołany sfingowanym przeniesieniem starego poety w ramy stylu życia nastolatka wzbudza u odbiorcy śmiech. Bećković świadomie podkreśla nieprzystawalność zwyczajów dwóch pokoleń i poprzez rozmaite zabiegi poetyckie (paralelizm, schematyczność budowy, powtórzenia) dodatkowo wzmacnia kontrasty między młodością a starością. Im większy entuzjazm dla parametrów ciała oraz osiągnięć branż kosmetycznej i medycznej wyraża podmiot liryczny, tym bardziej irrealne są jego deklaracje. Czytelnik zatem dość szybko się orientuje, że Bećković krytykuje propagowane trendy i radykalny zwrot w stronę ciała oraz wskazuje niedorzeczność poddawania się najstarszego pokolenia medialnej presji.

Sam ideał młodości przedstawiony zostaje na zasadach karykatury. Ponieważ kojarzone z nim elementy rzeczywistości ulegają przerysowaniom, dochodzi do ujawniania niedoskonałości ferowanego modelu i jego pośredniej degradacji.

${ }^{4}$ Matija Bećković (ur. 1939) - autor ponad 30 tytułów, poeta, dramaturg, aktor. Był prezesem Udruženja književnika Srbije (w latach 1988-1992), a od przeszło 30 lat należy do SANU. Za jeden ze swych najważniejszych tekstów sam uważa poemat Vera Pavladoljska, dzięki któremu przeniósł w świat literatury postać swej późniejszej małożnki, jednak szeroko identyfikowany jest raczej z tytułami: Lele i kuku (1978), Služba Svetom Savi (1988), Kosovo najskuplja sprska reč (1989), Ćereaćemo se još (1996), Hleba i jezika (1997). Teksty te w znacznej mierze wpisują się w retorykę dyskursu nacjonalistycznego. 
Bećković korzysta ze slangu, gromadzi wyrażenia w rodzaju: „kapiram”, „to je sve kul”, „trendi”, wprowadza mnóstwo fraz zaczerpniętych z języka agnielskiego. Uzyskuje dzięki temu efekt parodii języka młodzieżowego, lecz jednocześnie wskazuje, że źródło modnych a szkodliwych wzorców tkwi na Zachodzie.

Kierunek refleksji Bećkovicia w zasadzie wpisuje się w logikę tra d y c yjnego konfliktu międzypokoleniowego, układa się w spór starszego intelektualisty z młodymi, których wizerunek, najogólniej mówiąc, nie wykracza poza stereotypowe ujęcie utrwalone w przysłowiu: „Mladost je ludost” ${ }^{\text {. }} \mathrm{Z}$ pewnością ów antagonizm trzeba interpretować w szerszym kontekście jako emanację konserwatywnego dyskursu antyeuropejskiego i antymodernizacyjnego. Tym bardziej że w realność tekstu włączone zostają ważne argumenty aktualnej serbskiej debaty publicznej.

Poeta, obserwując Belgrad pierwszej dekady XXI wieku, dostrzega zjawiska właściwe dla społeczeństwa konsumpcyjnego, które opisywali wcześniej myśliciele zachodnioeuropejscy. Porusza pośrednio problem ponowoczesnej etyki zwanej etyką konsumpcji, o której w 1970 roku Jean Baudrillard pisał, że „nakazuje [ona] teraz wszystkim, by sami oddali się na służbę swojemu ciału”, gdyż zajęło ono miejsce duszy, nowego mitu, dogmatu, przedmiotu zbawienia. Starający się wpisać w ten nurt podmiot mówiący o poezji Bećkovicia wykazuje się znajmością funkcjonwania własnego organizmu, dokładnej budowy anatomicznej oraz przebiegu procesów fizjologicznych. Podkreśla także znaczenie wszelkich profesji związanych z dbałością o dobrostan ciała: lekarzy, dietetyków, terapeutów, trenerów. Przywołuje rozmaite rozwiązania technologiczne, które współczesnej medycynie umożliwiają kontrolę nad życiowymi parametrami. Wszystkie te kwestie hiperbolizuje i sytuuje w centrum zaintresowania młodych, gdyż, jego zdaniem, ich obsesyjna, fetyszystyczna dbałość o ciało idzie w parze z narcyzmem. Czytamy: „Kad buem mlađi// Umeću da živim// Neće mi dani prolaziti kao dosad// Tek tako// Bez svrhe i smisla// Imaću vremena [...]// Ali ga neću traćiti na gluposti// Već svaki tren posvetiti sebi// [...] Rasporediti na svoja zadovoljstva"7. Poeta jako przewartościowany ukazuje więc także stosunek do czasu, który młody człowiek chce spożytkować na sprawy dlań istone, na to by być „vitak i lak”,,japi”, „fit”, ,jet set”, „VIP”. W ślad za tym idzie niski poziom kontaktów towarzyskich, a charakteru hasła przewodniego nabiera zdanie: „Ako si mi prijatelj// Idi kući// (Go home)" (B, 64). To samo dotyczy relacji rodzinnych, które zamieniły się w falę niewdzięczności względem sędziwych rodziców. „Kad budem mlađi// Prvo ću majku naučiti redu// Da mi ne telefonira// Nikako// Kamoli onako zadihano//Čim počne moja omiljena serija// I da se ne ljuti// Kad zajapurena doperja u posetu// Što je moj prvi refleks// Da se popnem na bicikl// I ne gubim vreme" (B, 64).

${ }^{5}$ Por. Jednostavni oblici narodne književnosti, prired. M. Kleut, Novi Sad 2010.

${ }^{6}$ J. Baudrillard, op. cit. s. 188.

${ }^{7}$ M. Bećković, Kad budem mlađi, Novi Sad 2007, s. 7. W kolejnych cytatach będę korzystać $\mathrm{z}$ tego wydania książki. 
W poezji Bećkovicia zawarta jest także kontestacja modnych zachowań prozdrowotnych. Dotyczą one kulinarnej dysycpliny, praktyk antynikotynowych, wszelkiej profilaktyki, która zostaje zamieniona w farsę. Niechaj za ilustrację kpiarskiego tonu wywodu posłużą słowa: „Kad budem mlađi// Cigarete ću naterati// Da pre ostave mene// Nego ja njih".

Co ciekawe, Bećković nawiązuje bezpośrednio do krytyki SANU, ale fragment ten ma mieć raczej charakter parodii dyskusji na temat tej instytucji lub samych jej oponentów, ponieważ ich reprezentantem jest ignorant wypowiadający zdanie: „Nema sile da me navataju// I upišu u tu faunu// Matorih destruktivaca// I okljocanih luzera (Čitaj ratnih huskača// I klerofašista)// Zaobilaziću tu zgradu// Na putu u diskoteku" (B, 77). W ostatnich partiach utworu Bećković prześmiewczo mówi także o poczuciu tożsamości wśród młodych, Serbia w ich oczach to mizerny kraj, a jego obywatele mają zbyt długie i zbyt trudne nazwiska, na które nikt nie zwraca uwagi.

Nema smisla pripadati// luzerskim nacijama// kojima svi drže laktove pod grlom// i ceo vek// ma ko da si// provesti u Srbiji// gde Zapad pravi pauzu// od nekoliko stotina kilometara// i nastavlja u Bugarskoj// na putu u budućnost// ostavljajući nas same// usred ničega (B, 115-116).

„Kad budem mlađi// Neću živeti ovde// Nema šansone// No chance” (B, 118) — ma mówić reprezentant młodego pokolenia, udajcy się na emigrację. Dalej zaś tłumaczy, że nie ucieka, lecz wyjeżdża, bo nie wierzy w zdolności intelektualne rodaków i chce się po prostu wzbogacić.

Bećković, tłumacząc łatwość, z jaką rozpowszechnia się modny styl życia, wpada w koleiny bałkanizmu, ponieważ twierdzi, że jest ona wynikiem kompleksów i zadawnionej pogoni za tym, co cywilizowane. Łączą się w jego wywodach represjonujące dyskursy oparte na bipolarnej logice — jak antyokcydentalizm ze wspomnianym bałkanizmem, przeplatają się konceptualizowane na zasadzie opozycji pojęcia: świat zacofany-świat nowoczesny, Serbia-Zachód, św. SawaAngelina Jolie, Matica srpska-Costa Coffee. Co więcej, wszystkie te symboliczne, lecz bardzo uproszczone kontrasty zostają zamknięte w nadrzędnej opozycji młodzi-starzy. Oparcie całego tomu na koncepcie dychotomicznej struktury jest bardzo efektywne retorycznie. Trzeba jednak podkreślić, że zapalczywa krytyka skierowana jest przeciw grupie ludzi młodych, postrzeganych w sposób homogeniczny. I tu rodzi się poważna wątpliwość, czy negatywna emocjonalnie, oparta na stereotypach i przynależności wiekowej wypowiedź krytyczna, kontynuowana dalej w zbiorze Kad budem još mlađi (2012), jest jeszcze osobistą i poetycką, czy może już propagandową i polityczną ${ }^{8}$. Wydaje się, że nie można pozostać przy stwiedzeniu, iż mamy do czynienia jedynie z zajadłą satyrą. Wyjście poza ramy teorii literatury jest konieczne, ponieważ tekst Bećkovicia balansuje na granicy między kontestacją zachowania danej grupy społecznej a językiem nienawiści pogłębiającym społeczno-polityczne animozje.

\footnotetext{
${ }^{8}$ Por. www.mowanienawisci.info [dostęp: 7.10.2015].
} 
W zaprawionych komizmem wierszach starego poety (trzeba przyznać bardzo sprawnego warsztatowo) ludyczność łączy się z deklaracją określonych przekonań. Obok uwag o depilacji, o wynikach badań krwi i poziomie cholesterolu, autor umieszcza argumenty dotyczące poważnej dyskusji o modelach współczenego patriotyzmu. Wprost drwi z preferowanych przez młodych postaw obywatelskich, co możemy zaobserwować w cytacie: „Ako ispoštuješ creva// Ispoštovao si i svoj narod// Za koji najviše činiš ako se redovno olakšavaš // I čistiš đubre pred svojom kućom" (B, 53-54). Bećković wprowadza także bezpardonowe aluzje polityczne, w ramach których posługuje się retoryką antyamerykańską. Równolegle umniejsza znaczenie przemian demokratycznych w Serbii, groteskowo zestawiając symboliczną datę 5 października 2000 z napływem do kraju negatywnych zjawisk, które dawniej widywało się tylko w filmach obcej produkcji. $\mathrm{Z}$ drugiej strony zaś zachęca do quasi-reinterpretacji bitwy kosowskiej, dywagując, czy przypadkiem nie warto sprawdzić, czy i o jej przebiegu nie zadecydowała diametralnie zła dieta średniowiecznego rycerstwa serbskiego.

Mimochodem, lecz bezpośrednio, Bećković nawiązuje także do innych kwestii światopoglądowych. Za zgubne dla Serbii uważa, jak to określa, lewackie prądy intelektualne, a w jednym $\mathrm{z}$ wierszy zamykających tom odwołuje się do dyskusji na temat pojęcia narodu. Ponieważ wie, że ten koncept w ostatnim ćwierćwieczu wywoływał burzliwe spory, Bećković obiecuje przestać go traktować jako kategorię interpretacyjną. Jednak szybko okazuje się, że i ta propozycja jest absurdalnym żartem, a poeta pisze: „Kad budem mlađi// Za mene neće postojati vere i nacije// Već ljudi i neljudi// Ljudi koji jedu zrnasto// I neljudi koji jedu čorbasto" (B, 119).

Perspektywa oglądu młodości i starości, jaką w najnowszych sztukach przyjmuje Biljana Srbljanović ${ }^{9}$, jest bardziej wielowymiarowa i postpolityczna ${ }^{10}$. Dramatopisarka nie stawia się w sytuacji rzecznika którejkolwiek z grup społecznych, lecz pozostaje raczej zaangażowanym emocjonalnie obserwatorem, który stara się zdefiniować źródła poważnych napięć. Przedstawia ona problem starości w kontekście ważnych przemian społecznych i na tym poziomie można dostrzec w jej utworach wiele zbieżności z uwagami Bećkovicia. Dotyczą one

${ }^{9}$ Biljana Srbljanović (ur. 1970) — znana z krytyki nacjonalizmu dramatopisarka, której sztuki są wystawiane na deskach europejskich teatrów (na scenie belgradzkiej aktualnie dwa tytuły: Skakavci i Barbelo, o psima i deci. Laureatka licznych krajowych i zagranicznych nagród za najlepszy dramat. Swą najnowszą sztukę - Mali mi je ovaj grob - przygotowała w kooperacji serbsko-chorwacko-bośniackiej. W 2008 roku była kandydatką Partii Liberalno-Demokratycznej na prezydenta Belgradu. Aktywnie uczestniczy w życiu publicznym Serbii oraz w europejskich wydarzeniach kulturalnych. Jest współautorką scenariusza do serialu Otvorena vrata. Wykłada na Wydziale Sztuk Dramatycznych w Belgradzie.

${ }^{10}$ Por. A. Vujanović, Policje i polityki performatywności (Towar tatwopalny. Obchodzić się ostrożnie), przeł. D. Jovanka Ćirlić, [w:] Bałkany performatywne. Rytuat - dramat - sztuka w przestrzeni publicznej, red. M. Sztandara, G. Injac, W. Kuligowski, Opole 2013, s. 18; G. Injac, Nie rozpoznaję tego gatunku - dramat jako struktura polityczna, [w:] Postpolityczność. Antologia nowego dramatu serbskiego, wybór i redakcja G. Injac, Kraków 2011, s. 14-15. 
głównie powszechnego kultu młodości oraz lęku przed starością, jak również osamotnienia ludzi starych spowodowanego tym, że rodzina przestała być podstawowym punktem odniesienia $\mathrm{w}$ zatomizowanym społeczeństwie ${ }^{11}$. Problemy te Srbljanović omawia w dramatach związanych z krytyką serbskiej tranzycji. W sztukach takich jak: Skakavci (2005) (Szarańcza, 2008), Barbelo, o psima i o deci (2007) (Barbelo, o psach i dzieciach, 2011) i Nije smrt biciklo (da ti ga ukradu) (2011) (Śmierć nie jest rowerem (by ci go skradziono) — utwór nie został wydany w języku polskim) zbudowane zostały wielopoziomowe układy międzyludzkich relacji, dzięki którym kategoria wieku jest eksponowana na różne sposoby.

Dramatopisarka pokazuje, że określenia metrykalne są mocno naznaczone kulturowo, a dyskurs o wieku jest coraz bardziej istotny i „wrażliwy”. W dialogach swych bohaterów często umieszcza ona formulę: „, tvojim godinama...”, podkreślając, że zapisane w języku i będące w powszechnym użyciu stereotypy implikują konkretne, choć nie zawsze uświadomione, oczekiwania społeczne i nieformalnie regulują normy zachowania. Srbljanović nie zajmuje się jednak kwestią dyskryminacji ze względu na wiek, lecz kładzie raczej nacisk na filozoficzną i psychologiczną stronę procesu starzenia się, ujmowanego w sposób jednostkowy. Najważniejsze dla niej okazuje się zagadnienie psychicznej starości, którą w sposób interesujący definiuje polska feministka, Kinga Dunin:

Zestarzeć się duchowo to znaczy [...] pozwolić sobie na to, by poczuć się starą i zmęczoną. Nie mieć już na nic ochoty. $Z$ dystansem spojrzeć na wszystkie cele, do których z takim zapałem dążymy. Zadać sobie pytanie o sens naszego życia. I wreszcie spojrzeć w oczy prawdzie: to wszystko prowadzi do śmierci ${ }^{12}$.

Zjawisko to Srbljanović przypisuje pokoleniu ludzi metrykalnie jeszcze młodych, co do których możemy tylko przypuszczać, że urodzili się w latach siedemdziesiątych, a wspólnym dla nich doświadczeniem była przypadająca na początki dorosłości wojna w Jugosławii. Tę grupę postaci omówię jako pierwszą.

Zdecydowaną większość wśród tych paradoksalnie najstarszych bohaterów Srbljanović stanowią kobiety, często postaci pierwszoplanowe, pozostające w silnym związku emocjonalnym z jednym z bliskich krewnych, choć wcale z nim niezamieszkujące. Cechuje je bardzo wysoki stopień empatii i refleksyjności, ekstrawertyczność, szczery i „nierynkowy” stosunek do ludzi, który jest odbierany jako rodzaj braku przystosowania lub nieporadności. W życiu osobistym są samotne, lecz przejawiają silny instynkt opiekuńczy, uzewnętrzniający się we wrażliwości na potrzeby istot słabszych, na los zwierząt.

Wyrazistym przykładem takiej postaci jest Milena ze sztuki Barbelo... Bohaterka czuje się starsza od własnej matki, zarzuca ją trudnymi, życiowymi py-

11 Por. A. Giddens, Nowoczesność i tożsamość, przeł. A. Szulżycka, Warszawa 2006, s. $201-$ 202. W tym samym miejscu czytamy: „W warunkach przednowoczesnych różnego rodzaju więzy pokrewieństwa stanowiły na ogół jednoznaczny zewnętrzny kontekst doświadczenia jednostki”.

12 K. Dunin, op. cit., s. 57. 
taniami, dotyczącymi rozmaitych aspektów własnego niezrealizowanego macierzyństwa. Szczególny wydaje się stosunek Mileny do śmierci. Mertykalnie młoda kobieta trwa w stanie egzystencjalnego lęku i inercji, nie wierzy w metafizyczne tradycje, w „opowieści dla dzieci” oraz religijne rytuały. Dojmująca smotność, towarzyszące jej silne poczucie nonsensu, rezygnacji, bezsilności oraz świadomość nieuchronnego kresu rzeczywiście czynią z niej postać przygnębiającą i zdezintegrowaną.

Podobną konstrukcję psychiczną ma Nadežda z utworu Nije smrt biciklo... Autorka opisuje ją jako starą kobietę, która kończy czterdziestkę. Poznajemy ją w belgradzkim szpitalu, gdzie zabiega o poradę lekarską dla osiemdziesięcioletniego ojca. Córka traktuje starszego z szacunkiem i cierpliwością, choć jest to nie lada wyzwaniem, zważywszy na jego grubiańskie zachowania, brak posłuchu, wyszydzanie, które, jak się dowiadujemy, jest już tylko złagodzonym, końcowym etapem długiego procesu psychicznej i fizycznej przemocy. Kobieta wie, komu zawdzięcza trapiące ją poczucie nieudolności, a jednak zachowuje wyrozumiałość dla rodzica, jego lęków i słabości.

Z kolei Nadežda ze sztuki Skakavci jest nieco bardziej pogodnym wariantem młodej staruszki. To postać dynamiczna, umiejscowiona w wielu kontekstach społecznch, bardziej aktywna i temperamentna. Nadežda jest naturalną, prostoduszną, bystrą i rozmowną osobą, która pracuje jako charakteryzatorka w telewizji. Nie ma ambicji zostania gwiazdą, choć przebywa w świecie blichtru i pozorów, zamieszkałym przez tytułową „szarańczę”, środowisko konsumpcjonistów, egocentryków i megalomanów, hipokrytów i cyników. Na tym tle Nadežda mocno się wyróżnia wrażliwością, prostolinijnością i bezinteresownością. Ma również nietypowy stosunek do śmierci. Podczas gdy niektórzy jej znajomi boją się nawet wymawiać to słowo, ona preznetuje głęboką świadmość końca własnego istnienia, jest z tym faktem pogodzona, myśli o nim i mówi. Nie jest też osobowością narcystyczą, nie lubi się eksponować ani nie zabiega o prestiż. Bohaterka, choć jest kalendarzowo i fizycznie młoda, wyznaje, że czuje się stara, za stara na małżeństwo, macierzyństwo, frywolność. Odczuwa zupełną nieprzynależność do klasy ludzi młodych ${ }^{13}$.

Skądinąd, młodzi w sztuce Skakavci są ważnym obiektem krytyki. Postaci w średnim wieku wyrażają się o nich pejoratywnie, używając słów: „vaške, pacovi, bube, bubašvabe, viruse, govno, dlake"14, natomiast reprezentanci kalendarzowo najstarszej generacji zarzucają im brak ogłady oraz poszanowania dla podeszłego wieku. Młodzi, przedstawieni przez Srbljanović, potwierdzają słuszność tych zarzutów. Prezentowany przez nich stosunek do sędziwych bliskich jest ambiwalentny. Srbljanović w sztuce Skakavci pokazuje dużą rozpiętość reakcji w relacjach ludzi młodszych ze starszymi. Od czynienia uwag, ograniczania wza-

13 Z. Bauman, Życie na przemiat, przeł. T. Kunz, Kraków 2006, s. 204.

${ }_{14}$ B. Srbljanović, Skakavci, [w:] eadem, Barbelo, o psima i deci. Skakavci, Beograd 2007, s. 229. 
jemnych kontaktów i przesuwania na margines codziennej krzątaniny, poprzez agresywne napady złości, aż do chęci zupełnego pozbycia się człowieka starszego, traktowanego w kategoriach męczącego obowiązku.

Z kolei bohaterowie biologicznie najstarsi tworzą niejednolitą typologicznie grupę, nakreśloną z uwzględnieniem pewnej periodyzacji, opartej na poziomie psychofizycznej sprawności. Pierwszym z reprezentatywnych charakterów jest klasyczny zgryźliwiec uosabiany przez Drago ze sztuki Barbelo. Nie ufa on swoim dzieciom, dystansuje się od ich poczynań, podejrzewa o chęć materialnego wykorzystania, jest malkontentem tęskniącym za samotnością. Jego adwersarzem jest Mila. Ta stwierdza, że wygląda on na starca, po którym nikt nie uroni łzy. Mila z kolei ma etykietę ,jeszcze za młodej, by odejść”, choć wyraźnie doskwiera jej poczucie niedostosowania do tempa przemian we współczesnej rzeczywistości. Jest wewnętrznie rozdarta, gdyż ucieka od samotności, czyta i nie poddaje się zwątpieniu, jednocześnie ukrywając się przed towarzystwem nadmiernie refleksyjnej córki. Starsza kobieta zachowuje autonomię, ponieważ zdaje sobie sprawę, że nie jest $\mathrm{w}$ stanie sprostać stawianym pytaniom i udzielić oczekiwanych rad. Widać tu dwa ważne zjawiska społeczne okresu ponowoczesności: n i e w s półmierność doświadczeń wcześniejszych generacji z doświadczeniem młodszych, a więc konieczność poszukiwania rad raczej u ekspertów niż krewnych, a także przeniesienie odpowiedzialności za wybory podejmowane przez decydujące podmioty na nie same ${ }^{15}$. $\mathrm{Z}$ ust Mili padają też słowa o kondycji emerytów. Swych rówieśników kojarzy ona z „odpadami“ współczesności, dostrzega problem wykluczania z powodu choroby i biedy. Jej wypowiedź współbrzmi ze spostrzeżeniami Zygmunta Baumana, który zauważa, że dyskursy medialne ponowoczesności ferują tezy, iż

nikt poza kilkoma samotnymi zwycięzcami nie jest naprawdę niezbędny, że człowiek potrzebny jest innym ludziom jedynie tak długo, jak długo daje się go wykorzystać, że kosz na śmieci, ostateczne przeznaczenie wszystkich wykluczonych, jest naturalnym miejscem dla tych, których nie da się już wykorzystać lub którzy nie chcą być dłużej wykorzystywani ${ }^{16}$.

Mila należy także do wyjątkowej grupy bohaterów, którzy, jak to ujmuje Srbljanović, są „kao neki stari ljudi, a da uopšte nisu stari”"17. Ich atrybutem jest ławeczka w parku, są samodzielni, poruszają się w przestrzeni publicznej, lecz mimo że nie czują się w niej komfortowo i trudno im się w pełni zaadoptować w świecie nowych reguł życia społecznego, wciąż starają się komunikować z otoczeniem. Ta ostatnia zdolność współgra z obserwacją Marii Szyszkowskiej na temat prób zachowania psychicznej młodości. Polska filozofka zauważa bowiem, że nie poddać się upływowi czasu to znaczy postarać się o zachowanie młodzieńczej wrażliwości, entuzjazmu dla spraw i działań, które wiążą ze światem nowych pokoleń, pasji, twórczej postawy, kontaktu ze światem zewnętrz-

\footnotetext{
15 Por. A. Giddens, op. cit.

16 Z. Bauman, op. cit., s. 203.

${ }^{17}$ B. Srbljanović, Barbelo..., s. 69.
} 
nym $^{18}$. Cechy te można potraktować jako przeciwstawne dla pejoratywnych określeń, takich jak: „suvi starac”, „ljut starac”, stosowanych przez Srbljanović na określenie zgryźliwców.

Trzecią grupę postaci w podeszłym wieku stanowią ludzie niedołężni, wymagający opieki i poświęcenia ze strony innych. Są to jednostki osadzone w realiach własnego domu lub w szpitalu, otoczone sprzętami medycznymi, zdane na pomoc lekarzy (których ranga współcześnie niebywale wzrasta), wreszcie pozbawione kontroli nad własnym losem i ciałem. Srbljanović w utworze Skakavci zauważa zjawisko, które Maria Szyszkowska zręcznie określiła jako „wyobcowanie starych ludzi ze społeczności tych, którzy żyją złudzeniem własnej nieprzemijalności"19. Dramatopisarka stara się też pokazać, jak niełatwa jest opieka nad chorym bliskim, oraz porusza kwestię ukonstytuowanego w społeczeństwie ponowoczesnym zwyczaju izolowania osób umierających ${ }^{20}$, penalizację $^{21}$ i medykalizację śmierci:

A te noći je tata umro, sam kao pas. Jer ovde, kad neko umire, ne daju mu da bude okružen svojima. Šutnu te u neki ćošak i ujutru obaveste bližnje. Te noći, moj tata umire, na aparatima za disanje ${ }^{22}$.

Osobną grupę stanowią sędziwi intelektualiści ze sztuki Skakavci, będący ponad wszelką wątpliwość reprezentantami zasłużonch członków SANU. Srbljanović personifikuje tę instytucję jako klikę starych mężczyzn, bezwzględnie dążących do celu, jakim jest niepodważalne poczucie przynależności do warstwy najwybitniejszych krajowych intelektualistów. Ukazuje ich jako oportunistów i cyników kierujących się nieracjonalnymi ambicjami, poczuciem wyższości i władzy, dlatego również ich określa mianem „szarańczy”. By podsumować ten wątek powtarzający się u obojga serbskich twórców, warto zauważyć, że poruszenie przez Srbljanović i Bećkovicia kwestii Akademii jest ważnym sygnałem potwierdzającym aktualność sporu o jej kształt, znaczenie i misję. Pytania te łączą się z ważką kwestią kierunków oddziaływania elit na rozwój danego społeczeństwa.

Tom poetycki Matiji Bećkovicia Kad budem mlađi jest podwójnie krytyczny i wzbudzający kontrowersje. Z jednej strony brak akceptacji wycelowany jest $\mathrm{w}$ infantylizację popkultury nastawionej głównie na propagowanie witalności oraz w ludzi, którzy tej presji ulegają, z drugiej zaś buduje on oparty na polaryzacji schemat retoryczno-dedukcyjny, w którego wyniku powstaje sprawne narzędzie represji i agitacji politycznej, co jest bardzo istotne w kontekście znakomitej promocji oraz szerokiej recepcji tekstu. O ile Bećković przyjął uproszczoną i jednak dość agresywną strategię reagowania na zmiany społeczne, o tyle Biljana Srblja-

\footnotetext{
${ }^{18}$ Por. M. Szyszkowska, Spotkania w salonie, Warszawa 2000, s. 52.

19 Ibidem, s. 51.

20 Por. A. Giddens, op. cit., s. 221.

21 Por. M. Foucault, Narodziny kliniki, przeł. P. Pieniążek, Warszawa 1999.

22 B. Srbljanović, Nije smrt biciklo (da ti ga ukradu), Beograd 2011, s. 66.
} 
nović stara się pokazać szerokie spektrum problemów i wyjść poza granice stereotypów, unikając samonarzucających się wniosków. Szczególnie ciekawe wydaje się też uwzględnienie przez nią kategorii wieku psychicznego, która relatywizuje kwestie młodości i starości. W jednym z dramatów pada bardzo ważna deklaracja egzystencjalna: „Meni uopšte nije strašno da umrem. Strašno mi je samo da budem stara" ${ }^{23}$. Wskazuje ona na duże znaczenie procesu przygotowania do starości oraz filozoficznych poszukiwań własnego bezpieczeństwa ontologicznego.

\section{Bibliografia}

Baudrillard J., Społeczeństwo konsumpcyjne. Jego mity i struktury, przeł. S. Królak, Warszawa 2006.

Bauman Z., Życie na przemiał, przeł. T. Kunz, Kraków 2006.

Bećković M., Kad budem još mlađi, Beograd 2012.

Bećković M., Kad budem mlađi, Novi Sad 2007.

Dunin K., Czego chcecie ode mnie, Wysokie Obcasy?, Warszawa 2002.

Foucault M., Narodziny kliniki, przeł. P. Pieniążek, Warszawa 1999.

Giddens A., Nowoczesność i tożsamość, przeł. A. Szulżycka, Warszawa 2006.

Injac G., Nie rozpoznaję tego gatunku - dramat jako struktura polityczna, [w:] Postpolityczność. Antologia nowego dramatu serbskiego, wybór i redakcja G. Injac, Kraków 2011, s. 9-22.

Jednostavni oblici narodne književnosti, oprac. M. Kleut, Novi Sad 2010.

Srbljanović B., Barbelo, o psima i deci. Skakavci, Beograd 2007.

Srbljanović B., Nije smrt biciklo (da ti ga ukradu), Beograd 2011.

Szyszkowska M., Spotkania w salonie, Warszawa 2000.

Vujanović A., Policje i polityki performatywności (Towar łatwopalny. Obchodzić się ostrożnie), przeł. D. Jovanka Ćirlić, [w:] Bałkany performatywne. Rytuat - dramat - sztuka w przestrzeni publicznej, red. M. Sztandara, G. Injac, W. Kuligowski, Opole 2013, s. 13-22.

Wstęp do kulturoznawstwa, przeł. M. Kaczyński, J. Łoziński, T. Rosiński, Poznań 2007.

\section{About the young and the old in contemporary Serbian literature (Matija Bećković, Biljana Srbljanović)}

\section{Summary}

The Serbian writers from recent decades try to investigate a question of old age, antagonisms between generations and periodisation of the life stages in contex of social changes in the modern Europe. That article intends to show two very different ways of thinking about that problems and their discoursive background.

Keywords: old age, discourse, contemporary Serbian literature, ideology

23 B. Srbljanović, Skakavci..., s. 325. 


\section{O mladima i starima u savremenoj srpskoj književnosti (Matija Bećković, Biljana Srbljanović)}

\section{Rezime}

U stvaralaštvu savremenih srpskih pisaca teme uzrasta, starosti, antagonizma između generacija i različitih načina periodizacije egzistencije se posmatraju u kontekstu aktuelnih društvenih promena u Evropi. Ovaj članak donosi analizu dva različita načina književnog govora o navedenim problemima a takođe o njihovom diskurzivnom tlu. U pitanju su savremena poezija Matije Bećkovicia i stvaralaštvo Biljane Srbljanović.

Ključne reči: starost, diskurs, savremena srpska književnost, ideologija 